\title{
DAMPAK PENCEMARAN TANAH DAN LANGKAH PENCEGAHAN
}

\author{
Muslimah, S.Si,M.Si \\ Dosen Tetap Universitas Samudra
}

\begin{abstract}
ABSTRAK
Tanah merupakan bagian penting dalam menunjang kehidupan makhluk hidup di muka bumi. Seperti kita ketahui rantai makanan bermula dari tumbuhan. Manusia, hewan hidup dari tumbuhan. Memang ada tumbuhan dan hewan yang hidup di laut, tetapi sebagian besar dari makanan kita berasal dari permukaan tanah. Ketika suatu zat berbahaya/beracun telah mencemari permukaan tanah, maka ia dapat menguap, tersapu air hujan dan atau masuk ke dalam tanah. Pencemaran yang masuk ke dalam tanah kemudian terendap sebagai zat kimia beracun di tanah. Zat beracun di tanah tersebut dapat berdampak langsung kepada manusia ketika bersentuhan atau dapat mencemari air tanah dan udara di atasnya. Pencemaran tanah bisa disebabkan limbah domestik, limbah industri, dan limbah pertanian. Beberapa langkah penanganan untuk mengurangi dampak yang ditimbulkan oleh pencemaran tanah yaitu : Remediasi, Bioremediasi dan Fitoremediasi. Timbunan sampah yang berasal dari limbah domestik dapat mengganggu/ mencemari karena: lindi (air sampah), bau dan estetika. Timbunan sampah juga menutupi permukaan tanah sehingga tanah tidak bisa dimanfaatkan. Padatan, lumpur, bubur yang berasal dari proses pengolahan adalah limbah padat hasil buangan industri. Adanya reaksi kimia yang menghasilkan gas tertentu menyebabkan penimbunan limbah padat ini busuk selain itu pencemaran tanah juga menyebabkan timbulnya bau di sekitarnya. Karena tertimbunnya limbah ini dalam jangka waktu lama menyebabkan permukaan tanah menjadi rusak dan air yang meresap ke dalam tanah terkontaminasi bakteri tertentu dan berakibat turunnya kualitas air tanah pada musim kemarau oleh karena telah terjadinya pencemaran tanah. Timbunan yang mengering akan dapat mengundang bahaya kebakaran. Sisa hasil industri pelapisan logam yang mengandung zat-zat seperti tembaga, timbal, perak,khrom, arsen dan boron adalah limbah cair yang sangat beracun terhadap mikroorganisme. Peresapannya ke dalam tanah akan mengakibatkan kematian bagi mikroorganisme yang memiliki fungsi sangat penting terhadap kesuburan tanah dan dalam hal ini pun menyebabkan pencemaran tanah. Pupuk yang digunakan secara terus menerus dalam pertanian akan merusak struktur tanah, yang menyebabkan kesuburan tanah berkurang dan tidak dapat ditanami jenis tanaman tertentu karena hara tanah semakin berkurang. Dalam kondisi ini tanpa disadari justru pupuk juga mengakibatkan pencemaran tanah. Pestisida yang digunakan bukan saja mematikan hama tanaman tetapi juga mikroorga-nisme yang berguna di dalam tanah. Padahal kesuburan tanah tergantung pada jumlah organisme di dalamnya. Selain pencemaran tanah penggunaan pestisida yang terus menerus akan mengakibatkan hama tanaman kebal terhadap pestisida tersebut. Selain itu pada berbagai bidang dampak yang ditimbulkan akibat pencemaran tanah, diantaranya adalah: Dampak pencemaran tanah terhadap kesehatan tergantung pada tipe polutan, jalur masuk ke dalam tubuh dan kerentanan populasi yang terkena. Kromium, berbagai macam pestisida dan herbisida merupakan bahan karsinogenik untuk semua populasi. Timbal sangat berbahaya pada anak-anak, karena dapat menyebabkan kerusakan otak, serta kerusakan ginjal pada seluruh populasi. Paparan kronis (terus-menerus) terhadap benzena pada konsentrasi tertentu dapat meningkatkan kemungkinan terkena leukemia. Merkuri (air raksa) dan siklodiena dikenal dapat menyebabkan kerusakan ginjal, beberapa bahkan tidak dapat diobati. PCB dan siklodiena terkait pada keracunan hati. Organofosfat dan karmabat dapat menyebabkan gangguan pada saraf otot. Berbagai pelarut yang mengandung klorin merangsang perubahan pada hati dan ginjal serta penurunan sistem saraf pusat. Terdapat beberapa macam dampak kesehatan yang tampak seperti sakit kepala, pusing, letih, iritasi mata dan ruam kulit untuk paparan bahan kimia yang disebut di atas. Yang jelas, pada dosis yang besar, pencemaran tanah dapat menyebabkan Kematian.

Pencemaran tanah juga dapat memberikan dampak terhadap ekosistem. Perubahan kimiawi tanah yang radikal dapat timbul dari adanya bahan kimia beracun/berbahaya bahkan pada dosis yang rendah sekalipun. Perubahan ini dapat menyebabkan perubahan metabolisme dari mikroorganisme endemik dan antropoda yang hidup di lingkungan tanah tersebut. Akibatnya bahkan dapat memusnahkan beberapa spesies primer dari rantai makanan, yang dapat memberi akibat yang besar terhadap predator atau tingkatan lain dari rantai makanan tersebut. Bahkan jika efek kimia pada bentuk kehidupan terbawah tersebut rendah, bagian bawah piramida makanan dapat menelan bahan kimia asing yang lama-kelamaan akan terkonsentrasi pada makhluk-makhluk penghuni piramida atas. Banyak dari efek-efek ini terlihat pada saat ini, seperti konsentrasi DDT pada burung menyebabkan rapuhnya cangkang telur, meningkatnya tingkat Kematian anakan dan kemungkinan hilangnya spesies tersebut. Dampak pada pertanian terutama perubahan metabolisme tanaman yang pada akhirnya dapat menyebabkan penurunan hasil pertanian. Hal ini dapat menyebabkan dampak lanjutan pada konservasi tanaman di mana tanaman tidak mampu menahan lapisan tanah dari erosi. Beberapa bahan pencemar ini memiliki waktu paruh yang panjang dan pada kasus lain bahan-bahan kimia derivatif akan terbentuk dari bahan pencemar tanah utama.
\end{abstract}

Kata Kunci: Pencemaran, Konservasi, Tanah, Bahan Kimia, Dampak 


\section{PENDAHULUAN}

Pertambahan jumlah penduduk serta peningkatan jumlah kegiatan pembangunan yang mengakibatkan terjadinya pergeseran pola penggunaan lahan di Indonesia. Sering dijumpai pola penggunaan lahan yang tidak sesuai dengan kaidah penataan ruang dan kemampuan serta kesesuaian lahan, sehingga timbul masalah seperti lahan kritis, hilangnya lahan pertanian yang subur, dan terjadinya pencemaran tanah. Pertumbuhan ekonomi dan industri yang menyebabkan terjadinya kecenderungan kepada perubahan siklus alami, terutama mengenai perubahan-perubahan sungai dan kegiatan lain yang dapat mengurangi produktivitas biologis. Tanah merupakan bagian penting dalam menunjang kehidupan makhluk hidup di muka bumi. Seperti kita ketahui rantai makanan bermula dari tumbuhan. Manusia, hewan hidup dari tumbuhan. Memang ada tumbuhan dan hewan yang hidup di laut, tetapi sebagian besar dari makanan kita berasal dari permukaan tanah. Oleh sebab itu, sudah menjadi kewajiban kita menjaga kelestarian tanah sehingga tetap dapat mendukung kehidupan di muka bumi ini. Akan tetapi, sebagaimana halnya pencemaran air dan udara, pencemaran tanah pun akibat kegiatan manusia juga.

Namun seiring berjalannya waktu, kesuburan yang dimiliki oleh tanah Indonesia banyak yang digunakan sesuai aturan yang berlaku tanpa memperhatikan dampak jangka panjang yang dihasilkan dari pengolahan tanah tersebut. Salah satu diantaranya, penyelenggaraan pembangunan Pembangunan kawasan industri di daerah-daerah pertanian dan sekitarnya menyebabkan berkurangnya luas areal pertanian, pencemaran tanah dan badan air yang dapat menurunkan kualitas dan kuantitas hasil/produk pertanian, terganggunya kenyamanan dan kesehatan manusia atau makhluk hidup lain.
Dampak negatif yang menimpa lahan pertanian dan lingkungannya perlu mendapatkan perhatian yang serius, karena limbah industri yang mencemari lahan pertanian tersebut mengandung sejumlah unsur-unsur kimia berbahaya yang bisa mencemari badan air dan merusak tanah dan tanaman serta berakibat lebih jauh terhadap kesehatan makhluk hidup

\section{PENCEMARAN LINGKUNGAN}

Pencemaran lingkungan adalah masuknya atau dimasukkannya mahluk hidup, zat energi, dan atau komponen lain ke dalam lingkungan atau berubahnya tatanan lingkungan oleh kegiatan manusia atau oleh proses alam sehingga kualitas lingkungan turun sampai ke tingkat tertentu yang menyebabkan lingkungan menjadi kurang atau tidak dapat berfungsi lagi.

Zat atau bahan yang dapat mengakibatkan pencemaran di sebut polutan. Syarat-syarat suatu zat disebut polutan bila keberadaannya dapat menyebabkan kerugian terhadap makluk hidup. Contohnya, karbon dioksida dengan kadar 0,033\% di udara berfaedah bagi tumbuhan, tetapi bila lebih tinggi dari 0,033\% dapat memberikan efek merusak.

Suatu zat dapat disebut polutan apabila :

1. Jumlahnya melebihi jumlah normal.

2. Berada pada waktu yang tidak tepat.

3. Berada di tempat yang tidak tepat.

Sifat polutan adalah :

1. Merusak untuk sementara, tetapi bila telah bereaksi dengan zat lingkungan tidak merusak lagi.

2. Merusak dalam waktu lama.

Contohnya $\mathrm{Pb}$ tidak merusak bila konsentrasinya rendah. Akan tetapi dalam jangka waktu yang lama, $\mathrm{Pb}$ dapat terakumulasi dalam tubuh sampai tingkat yang merusak

\section{PENCEMARAN TANAH}

Pencemaran tanah adalah keadaan di mana bahan kimia buatan manusia masuk dan merubah lingkungan tanah alami. Pencemaran ini biasanya terjadi karena: kebocoran limbah 
cair atau bahan kimia industri atau fasilitas komersial; penggunaan pestisida; masuknya air permukaan tanah tercemar ke dalam lapisan sub-permukaan; kecelakaan kendaraan pengangkut minyak, zat kimia, atau limbah; air limbah dari tempat penimbunan sampah serta limbah industri yang langsung dibuang ke tanah secara tidak memenuhi syarat (illegal dumping).

Ketika suatu zat berbahaya/beracun telah mencemari permukaan tanah, maka ia dapat menguap, tersapu air hujan dan atau masuk ke dalam tanah. Pencemaran yang masuk ke dalam tanah kemudian terendap sebagai zat kimia beracun di tanah. Zat beracun di tanah tersebut dapat berdampak langsung kepada manusia ketika bersentuhan atau dapat mencemari air tanah dan udara di atasnya.

Menurut Peraturan Pemerintah RI No. 150 tahun 2000 tentang Pengendalian kerusakan tanah untuk produksi bio massa: "Tanah adalah salah atu komponen lahan berupa lapisan teratas kerak bumi yang terdiri dari bahan mineral dan bahan organik serta mempunyai sifat fisik, kimia, biologi, dan mempunyai kemampuan menunjang kehidupan manusia dan makhluk hidup lainnya. Tetapi apa yang terjadi, akibat kegiatan manusia, banyak terjadi kerusakan tanah. Di dalam PP No. 150 th. 2000 di sebutkan bahwa "Kerusakan tanah untuk produksi biomassa adalah berubahnya sifat dasar tanah yang melampaui kriteria baku kerusakan tanah". Ketika suatu zat berbahaya/beracun telah mencemari permukaan tanah, maka ia dapat menguap, tersapu air hujan dan atau masuk ke dalam tanah. Pencemaran yang masuk ke dalam tanah kemudian terendap sebagai zat kimia beracun di tanah. Zat beracun di tanah tersebut dapat berdampak langsung kepada manusia ketika bersentuhan atau dapat mencemari air tanah dan udara di atasnya.

\section{Penyebab Pencemaran Tanah}

Tanah adalah bagian penting dalam menunjang kehidupan makhluk hidup di muka bumi. Kita ketahui rantai makanan bermula dari tumbuhan. Manusia, hewan hidup dari tumbuhan. sebagian besar makanan kita berasal dari permukaan tanah, walaupun memang ada tumbuhan dan hewan yang hidup di laut. Sudah sepatutnya kita menjaga kelestarian tanah sehingga bisa mendukung kehidupan di muka bumi ini. Sebagaimana pencemaran air dan udara, pencemaran tanah pun merupakan akibat kegiatan manusia.

\section{Sumber Bahan Pencemar Tanah}

Pencemar tanah mempunyai hubungan erat dengan pencemaran udara dan pencemaran air, makan sumber pencemar udara dan sumber pencemar air pada umumnya juga merupakan sumber pencemar tanah. Sebagai contoh gasgas oksida karbon, oksida nitrogen, oksida belerang yang menjadi bahan pencemar udara yang larut dalam air hujan dan turun ke tanah dapat menyebabkan terjadinya hujan asam sehingga menimbulkan terjadinya pencemaran pada tanah. Air permukaan tanah yang mengandung bahan pencemar misalnya tercemari zat radioaktif, logam berat dalam limbah industri, sampah rumah tangga, limbah rumah sakit, sisa-sisa pupuk dan pestisida dari daerah pertanian, limbah deterjen, akhirnya juga dapat menyebabkan terjadinya pencemaran pada tanah daerah tempat air permukaan ataupun tanah daerah yang dilalui air permukaan tanah yang tercemar tersebut.

\section{Komponen Bahan Pencemar Tanah}

Komponen-komponen bahan pencemar yang diperoleh dari sumber-sumber bahan pencemar tersebut di atas antara lain berupa:

a) Senyawa organik yang dapat membusuk karena diuraikan oleh mikroorganisme, seperti sisa-sisa makanan, daun, tumbuhtumbuhan dan hewan yang mati. 
b) Senyawa organik dan senyawa anorganik yang tidak dapat dimusnahkan/ diuraikan oleh mikroorganisme seperti plastik, serat, keramik, kaleng-kaleng dan bekas bahan bangunan, menyebabkan tanah menjadi kurang subur.

c) Pencemar Udara berupa gas yang larut dalam air hujan seperti oksida nitrogen (NO dan NO2), oksida belerang (SO2 dan SO3), oksida karbon (CO dan CO2), menghasilkan hujan asam yang akan menyebabkan tanah bersifat asam dan merusak kesuburan tanah/ tanaman.

d) Pencemar berupa logam-logam berat yang dihasilkan dari limbahindustri seperti $\mathrm{Hg}, \mathrm{Zn}$, $\mathrm{Pb}, \mathrm{Cd}$ dapat mencemari tanah.

e) Zat radioaktif yang dihasilkan dari PLTN, reaktor atom atau dari percobaan lain yang menggunakan atau menghasikan zat radioaktif.

Pencemaran tanah bisa disebabkan limbah domestik, limbah industri, dan limbah pertanian

1) Limbah domestik

Limbah domestik yang bisa menyebabkan pencemaran tanah bisa berasal dari daerah: pemukiman penduduk; perdagangan/pasar/tempat usaha hotel dan lain-lain; kelembagaan misalnya kantor-kantor pemerintahan dan swasta; dan wisata, bisa berupa limbah padat dan cair.

1. Limbah padat berbentuk sampah anorganik. Jenis sampah ini tidak bisa diuraikan oleh mikroorganisme (non-biodegradable), misalnya kantong plastik, bekas kaleng minuman, bekas botol plastik air mineral, dsb.

2. Limbah cair berbentuk; tinja, deterjen, oli, cat, jika meresap kedalam tanah akan merusak kandungan air tanah dan bisa membunuh mikro-organisme di dalam tanah.

\section{2) Limbah industri}

Limbah industri yang bisa menyebabkan pencemaran tanah berasal dari daerah: pabrik,
Manufaktur, industri kecil, industri perumahan, bisa berupa limbah padat dan cair.

1. Limbah industri yang padat atau limbah padat yang adalah hasil buangan industri berupa padatan, lumpur, bubur yang berasal dari proses pengolahan. Misalnya sisa pengolahan pabrik gula, pulp, kertas, rayon, plywood, pengawetan buah, ikan daging dll.

2. Limbah cair yang adalah hasil pengolahan dalam suatu proses produksi, misalnya sisasisa pengolahan industri pelapisan logam dan industri kimia lainnya. Tembaga, timbal, perak, khrom, arsen dan boron adalah zat hasil dari proses industri pelapisan logam

\section{3) Limbah pertanian}

Limbah pertanian yang bisa menyebabkan pencemaran tanah merupakan sisa-sisa pupuk sintetik untuk menyuburkan tanah/tanaman, misalnya pupuk urea, pestisida pemberantas hama tanaman, misalnya DDT (Dichloro Diphenyl Trichlorethane).

Dua sifat buruk yang menyebabkan DDT sangat berbahaya terhadap lingkungan hidup adalah:

1. Sifat apolar DDT: ia tak larut dalam air tapi sangat larut dalam lemak. Makin larut suatu insektisida dalam lemak (semakin lipofilik) semakin tinggi sifat apolarnya. Hal ini merupakan salah satu faktor penyebab DDT sangat mudah menembus kulit.

2. Sifat DDT yang sangat stabil dan persisten. la sukar terurai sehingga cenderung bertahan dalam lingkungan hidup, masuk rantai makanan (foodchain) melalui bahan lemak jaringan mahluk hidup. Itu sebabnya DDT bersifat bioakumulatif dan biomagnifikatif. Karena sifatnya yang stabil dan persisten, DDT bertahan sangat lama di dalam tanah; bahkan DDT dapat terikat dengan bahan organik dalam partikel tanah. Dalam ilmu lingkungan, DDT termasuk dalam urutan ke 3 dari polutan 
organik yang persisten (Persistent Organic Pollutants, POP), yang memiliki sifat-sifat berikut:

a) Tak terdegradasi melalui fotolisis, biologis maupun secara kimia,

b) Berhalogen (biasanya klor),

c) Daya larut dalam air sangat rendah,

d) Sangat larut dalam lemak,

e) Semivolatile,

f) Di udara dapat dipindahkan oleh angin melalui jarak jauh,

g) Bioakumulatif,

Pengaruh buruk DDT terhadap lingkungan sudah mulai tampak sejak awal penggunaannya pada tahun 1940-an, dengan menurunnya populasi burung elang sampai hampir punah di Amerika Serikat. Dari pengamatan ternyata elang terkontaminasi DDT dari makanannya (terutama ikan sebagai mangsanya) yang tercemar DDT. DDT menyebabkan cangkang telur elang menjadi sangat rapuh sehingga rusak jika dieram. Dari segi bahayanya, oleh EPA DDT digolongkan dalam bahan racun PBT (persistent, bioaccumulative, and toxic) material

\section{DAMPAK YANG DITIMBULKAN AKIBAT PENCEMARAN TANAH}

Timbunan sampah yang berasal dari limbah domestik dapat mengganggu/ mencemari karena: lindi (air sampah), bau dan estetika. Timbunan sampah juga menutupi permukaan tanah sehingga tanah tidak bisa dimanfaatkan. Timbunan sampah bisa menghasilkan gas nitrogen dan asam sulfida, adanya zat mercury, chrom dan arsen pada timbunan sampah bisa timbulkan pencemaran tanah / gangguan terhadap bio tanah, tumbuhan, merusak struktur permukaan dan tekstur tanah. Limbah lainnya adalah oksida logam, baik yang terlarut maupun tidak menjadi racun di permukaan tanah.

Yang menyebabkan lapisan tanah tidak dapat ditembus oleh akar tanaman dan tidak biodegradasi, sehingga peresapan air dan mineral yang dapat menyuburkan tanah hilang dan jumlah mikroorganisme di dalam tanahpun akan berkurang, oleh sebab itu tanaman sulit tumbuh dan bahkan mati sebab tidak mendapatkan makanan untuk berkembang.

Tinja, deterjen, oli bekas, cat, adalah limbah cair rumah tangga; peresapannya kedalam tanah akan merusak kandungan air tanah dan zat kimia yang terkandung di dalamnya dapat membunuh mikro-organisme di dalam tanah, inilah salah satunya yang disebutkan sebagai pencemaran tanah.

Padatan, lumpur, bubur yang berasal dari proses pengolahan adalah limbah padat hasil buangan industri. Adanya reaksi kimia yang menghasilkan gas tertentu menyebabkan penimbunan limbah padat ini busuk selain itu pencemaran tanah juga menyebabkan timbulnya bau di sekitarnya. Karena tertimbunnya limbah ini dalam jangka waktu lama menyebabkan permukaan tanah menjadi rusak dan air yang meresap ke dalam tanah terkontaminasi bakteri tertentu dan berakibat turunnya kualitas air tanah pada musim kemarau oleh karena telah terjadinya pencemaran tanah. Timbunan yang mengering akan dapat mengundang bahaya kebakaran.

Sisa hasil industri pelapisan logam yang mengandung zat-zat seperti tembaga, timbal, perak,khrom, arsen dan boron adalah limbah cair yang sangat beracun terhadap mikroorganisme. Peresapannya ke dalam tanah akan mengakibatkan kematian bagi mikroorganisme yang memiliki fungsi sangat penting terhadap kesuburan tanah dan dalam hal ini pun menyebabkan pencemaran tanah.

Pupuk yang digunakan secara terus menerus dalam pertanian akan merusak struktur tanah, yang menyebabkan kesuburan tanah berkurang dan tidak dapat ditanami jenis tanaman tertentu karena hara tanah semakin berkurang. Dalam kondisi ini tanpa disadari 
justru pupuk juga mengakibatkan pencemaran tanah.

Pestisida yang digunakan bukan saja mematikan hama tanaman tetapi juga mikroorga-nisme yang berguna di dalam tanah. Padahal kesuburan tanah tergantung pada jumlah organisme di dalamnya. Selain pencemaran tanah penggunaan pestisida yang terus menerus akan mengakibatkan hama tanaman kebal terhadap pestisida tersebut.

Selain itu pada berbagai bidang dampak yang ditimbulkan akibat pencemaran tanah, diantaranya adalah:

\section{Pada kesehatan}

Dampak pencemaran tanah terhadap kesehatan tergantung pada tipe polutan, jalur masuk ke dalam tubuh dan kerentanan populasi yang terkena. Kromium, berbagai macam pestisida dan herbisida merupakan bahan karsinogenik untuk semua populasi. Timbal sangat berbahaya pada anak-anak, karena dapat menyebabkan kerusakan otak, serta kerusakan ginjal pada seluruh populasi.

Paparan kronis (terus-menerus) terhadap benzena pada konsentrasi tertentu dapat meningkatkan kemungkinan terkena leukemia. Merkuri (air raksa) dan siklodiena dikenal dapat menyebabkan kerusakan ginjal, beberapa bahkan tidak dapat diobati. PCB dan siklodiena terkait pada keracunan hati. Organofosfat dan karmabat dapat menyebabkan gangguan pada saraf otot. Berbagai pelarut yang mengandung klorin merangsang perubahan pada hati dan ginjal serta penurunan sistem saraf pusat. Terdapat beberapa macam dampak kesehatan yang tampak seperti sakit kepala, pusing, letih, iritasi mata dan ruam kulit untuk paparan bahan kimia yang disebut di atas. Yang jelas, pada dosis yang besar, pencemaran tanah dapat menyebabkan Kematian.

\section{Pada Ekosistem}

Pencemaran tanah juga dapat memberikan dampak terhadap ekosistem. Perubahan kimiawi tanah yang radikal dapat timbul dari adanya bahan kimia beracun/berbahaya bahkan pada dosis yang rendah sekalipun. Perubahan ini dapat menyebabkan perubahan metabolisme dari mikroorganisme endemik dan antropoda yang hidup di lingkungan tanah tersebut. Akibatnya bahkan dapat memusnahkan beberapa spesies primer dari rantai makanan, yang dapat memberi akibat yang besar terhadap predator atau tingkatan lain dari rantai makanan tersebut. Bahkan jika efek kimia pada bentuk kehidupan terbawah tersebut rendah, bagian bawah piramida makanan dapat menelan bahan kimia asing yang lama-kelamaan akan terkonsentrasi pada makhluk-makhluk penghuni piramida atas. Banyak dari efek-efek ini terlihat pada saat ini, seperti konsentrasi DDT pada burung menyebabkan rapuhnya cangkang telur, meningkatnya tingkat Kematian anakan dan kemungkinan hilangnya spesies tersebut.

Dampak pada pertanian terutama perubahan metabolisme tanaman yang pada akhirnya dapat menyebabkan penurunan hasil pertanian. Hal ini dapat menyebabkan dampak lanjutan pada konservasi tanaman di mana tanaman tidak mampu menahan lapisan tanah dari erosi. Beberapa bahan pencemar ini memiliki waktu paruh yang panjang dan pada kasus lain bahanbahan kimia derivatif akan terbentuk dari bahan pencemar tanah utama.

\section{PENANGANAN YANG HARUS DILAKUKAN}

Pencegahan dan penanggulangan merupakan dua tindakan yang tidak dapat dipisah-pisahkan dalam arti biasanya kedua tindakan ini dilakukan untuk saling menunjang, apabila tindakan pencegahan sudah tidak dapat dilakukan, maka dilakukan langkah tindakan. Namun demikian pada dasarnya kita semua sependapat bahwa tindakan pencegahan lebih baik dan lebih diutamakan dilakukan sebelum pencemaran terjadi, apabila pencemaran sudah terjadi baik secara alami maupun akibat aktivisas manusia untuk memenuhi kebutuhan 
hidupnya, baru kita lakukan tindakan penanggulangan.

Tindakan pencegahan dan tindakan penanggulangan terhadap terjadinya pencemaran dapat dilakukan dengan berbagai cara sesuai dengan macam bahan pencemar yang perlu ditanggulangi. Langkah-langkah pencegahan dan penanggulangan terhadap terjadinya pencemaran antara lain dapat dilakukan sebagai berikut:

\section{Langkah pencegahan}

Pada umumnya pencegahan ini pada prinsipnya adalah berusaha untuk tidak menyebabkan terjadinya pencemaran, misalnya mencegah/mengurangi terjadinya bahan pencemar, antara lain:

1) Sampah organik yang dapat membusuk/diuraikan oleh mikroorganisme antara lain dapat dilakukan dengan mengukur sampah-sampah dalam tanah secara tertutup dan terbuka, kemudian dapat diolah sebagai kompos/pupuk. Untuk mengurangi terciumnya bau busuk dari gasgas yang timbul pada proses pembusukan, maka penguburan sampah dilakukan secara berlapis-lapis dengan tanah.

2) Sampah senyawa organik atau senyawa anorganik yang tidak dapat dimusnahkan oleh mikroorganisme dapat dilakukan dengan cara membakar sampah-sampah yang dapat terbakar seperti plastik dan serat baik secara individual maupun dikumpulkan pada suatu tempat yang jauh dari pemukiman, sehingga tidak mencemari udara daerah pemukiman. Sampah yang tidak dapat dibakar dapat digiling/dipotongpotong menjadi partikel-partikel kecil, kemudian dikubur.

3) Pengolahan terhadap limbah industri yang mengandung logam berat yang akan mencemari tanah, sebelum dibuang ke sungai atau ke tempat pembuangan agar dilakukan proses pemurnian.
4) Sampah zat radioaktif sebelum dibuang, disimpan dahulu pada sumursumur atau tangki dalam jangka waktu yang cukup lama sampai tidak berbahaya, baru dibuang ke tempat yang jauh dari pemukiman, misal pulau karang, yang tidak berpenghuni atau ke dasar lautan yang sangat dalam.

5) Penggunaan pupuk, pestisida tidak digunakan secara sembarangan namun sesuai dengan aturan dan tidak sampai berlebihan.

6) Usahakan membuang dan memakai detergen berupa senyawa organik yang dapat dimusnahkan/diuraikan oleh mikroorganisme.

\section{Langkah Penanganan}

Penanganan khusus terhadap limbah domestik yang berjumlah sangat banyak diperlukan agar tidak mencemari tanah. Pertama sampah tersebut kita pisahkan ke dalam sampah organik yang dapat diuraikan oleh mikroorganisme (biodegradable) dan sampah yang tidak dapat diuraikan oleh mikroorganisme (non-biodegradable). Akan sangat baik jika setiap rumah tangga bisa memisahkan sampah atau limbah atas dua bagian yakni organik dan anorganik dalam dua wadah berbeda sebelum diangkut ketempat pembuangan akhir.

Sampah organik yang terbiodegradasi bisa diolah, misalnya dijadikan bahan urukan, kemudian kita tutup dengan tanah sehingga terdapat permukaan tanah yang dapat kita pakai lagi; dibuat kompos; khusus kotoran hewan dapat dibuat biogas dll sehingga dalam hal ini bukan pencemaran tanah yang terjadi tetapi proses pembusukan organik yang alami.

Sampah anorganik yang tidak dapat diurai oleh mikroorganisme. Cara penanganan yang terbaik dengan daur ulang. Kurangilah penggunaan pupuk sintetik dan berbagai bahan kimia untuk pemberantasan hama seperti pestisida.

Limbah industri harus diolah dalam pengolahan limbah, sebelum dibuang kesungai 
atau kelaut. Kurangilah penggunaan bahanbahan yang tidak bisa diuraikan oleh mikroorganisme (non-biodegradable). Salah satu contohnya adalah dengan mengganti plastik sebagai bahan kemasan/pembungkus dengan bahan yang ramah lingkungan seperti dengan daun pisang atau daun jati

Ada beberapa langkah penanganan untuk mengurangi dampak yang ditimbulkan oleh pencemaran tanah. Diantaranya:

\section{Remediasi}

Remediasi adalah kegiatan untuk membersihkan permukaan tanah yang tercemar. Ada dua jenis remediasi tanah, yaitu in-situ (atau on-site) dan ex-situ (atau off-site). Pembersihan on-site adalah pembersihan di lokasi. Pembersihan ini lebih murah dan lebih mudah, terdiri dari pembersihan, venting (injeksi), dan bioremediasi.

Pembersihan off-site meliputi penggalian tanah yang tercemar dan kemudian dibawa ke daerah yang aman. Setelah itu di daerah aman, tanah tersebut dibersihkan dari zat pencemar. Caranya yaitu, tanah tersebut disimpan di bak/tanki yang kedap, kemudian zat pembersih dipompakan ke bak/tangki tersebut. Selanjutnya zat pencemar dipompakan keluar dari bak yang kemudian diolah dengan instalasi pengolah air limbah. Pembersihan off-site ini jauh lebih mahal dan rumit.

\section{Bioremediasi}

Bioremediasi adalah proses pembersihan pencemaran tanah dengan menggunakan mikroorganisme (jamur, bakteri). Bioremediasi bertujuan untuk memecah atau mendegradasi zat pencemar menjadi bahan yang kurang beracun atau tidak beracun (karbon dioksida dan air).

Selain langkah - langkah di atas terdapat pula teknologi yang digunakan untuk menangani dampak dari pencemaran tanah yaitu, Fitoromediasi. Fitoremediasi adalah teknologi pembersihan, penghilangan atau pengurangan polutan berbahaya, seperti logam berat, pestisida, dan senyawa organik beracun dalam tanah atau air dengan menggunakan bantuan tanaman (hiperakumulator plant). Terdapat beberapa keunggulan dari karakteristik tanaman hiperkumulator yaitu, mampu menyerap lebih dari 10.000 ppm Mn, Zn, Ni; menyerap lebih dari 1.000 ppm untuk $\mathrm{Cu}$ dan Se; dan menyarap lebih dari 100 ppm untuk Cd, $\mathrm{Cr}, \mathrm{Pb}$, dan Co.

\begin{tabular}{|l|l|}
\hline Jenis Tanaman & Unsur Yg Diserap \\
\hline Thlaspi caerulescens & Zink (Zn) dan Kadmium (Cd) \\
\hline Alyssum sp., Berkheya sp., Sebertia acuminate & Nikel (Ni) \\
\hline Brassicacea sp. & Sulfate \\
\hline Pteris vittata, Pityrogramma calomelanos & Arsenik (As) \\
\hline $\begin{array}{l}\text { Pteris vittata, Nicotiana tabacum, Liriodendron } \\
\text { tulipifera. }\end{array}$ & Mercuri (Hg) \\
\hline $\begin{array}{l}\text { Thlaspi caerulescens, Alyssum murale, Oryza sativa } \\
\text { Brassica sp. }\end{array}$ & $\begin{array}{l}\text { Senyawa organik (petroleum hydrocarbons, } \\
\text { PCBs, PAH, TCE juga TNT) }\end{array}$ \\
\hline Brassica juncea. & Emas (Au) \\
\hline
\end{tabular}




\section{Proses Fitoremediasi}

1. Phytoacumulation : tumbuhan menarik zat kontaminan sehingga berakumulasi disekitar akar tumbuhan

2. Rhizofiltration : proses adsorpsi / pengendapan zat kontaminan oleh akar untuk menempel pada akar.

3. Phytostabilization : penempelan zat-zat contaminan tertentu pada akar yang tidak mungkin terserap kedalam batang tumbuhan.

4. Rhyzodegradetion : penguraian zat-zat kontaminan oleh aktivitas microba

5. Phytodegradation : penguraian zat kontamin

6. Phytovolatization : transpirasi zat contaminan oleh tumbuhan dalam bentuk yang telah menjadi larutan terurai sebagai bahan yang tidak berbahaya

\section{Keuntungan Fitoremediasi}

1. Biaya operasi lebih murah

2. Tanaman juga dapat digunakan bahan bakar.

3. Pencemaran pada tanah bisa berkurang secara alamiah

4. Tanah juga akan mengalami perbaikan akibat adanya aktivitas akar.

5. Tanah menjadi lebih subur kembali.

6. Tanaman yang mampu menyerap unsur bernilai ekonomi seperti emas (au) dan nikel (ni) bisa digunakan untuk pertambangan.

7. Tanaman hiperakumulator masuk dalam kriteria tanaman dengan syarat tumbuh yang tidak membutuhkan nutrisi tinggi dan tidak rewel.

\section{PENUTUP}

\section{KESIMPULAN}

Pencemaran tanah adalah keadaan di mana bahan kimia buatan manusia masuk dan merubah lingkungan tanah alami. Pencemaran ini biasanya terjadi karena: kebocoran limbah cair atau bahan kimia industri atau fasilitas komersial; penggunaan pestisida; masuknya air permukaan tanah tercemar ke dalam lapisan sub-permukaan; kimia, atau limbah; air limbah dari tempat penimbunan sampah serta limbah industri yang langsung dibuang ke tanah secara tidak memenuhi syarat (illegal dumping).

Penanganan khusus terhadap limbah domestik yang berjumlah sangat banyak diperlukan agar tidak mencemari tanah. Pertama sampah tersebut kita pisahkan ke dalam sampah organik yang dapat diuraikan oleh mikroorganisme (biodegradable) dan sampah yang tidak dapat diuraikan oleh mikroorganisme (nonbiodegradable). Akan sangat baik jika setiap rumah tangga bisa memisahkan sampah atau limbah atas dua bagian yakni organik dan anorganik dalam dua wadah berbeda sebelum diangkut ketempat pembuangan akhir.

Penanganan limbah dan sampah yang mengakibatkan pencemaran tanah dapat dilakukan dengan beberapa cara yaitu, Remediasi, Bioremediasi dan dengan teknologi fitoremediasi. Walaupun beberapa cara telah dapat digunakan untuk mengurangi dampak dari pencemaran tanah namun alangkah baiknya jika kesadaran untuk menjaga kelestarian alam dan lingkungan lebih ditingkatkan.

Bahan bahan yang kita perlukan dalam memenuhi kebutuhan dapat diperoleh dari tanah. Karenanya mari kita menghindari pencemaran tanah bersama-sama menjaga kelestariannya, demi kelangsungan anak, cucu kita dimasa datang.

\section{DAFTAR PUSTAKA}

Baehaki. 1993. Insektisida Pengendalian Hama Tanaman. Percetakan ANGKASA, Bandung.

Bachri, Moch. 1995. Geologi Lingkungan. CV. Aksara, Malang. 112 hal

McArmand Zurhaar. 2008. Pencemaran Tanah http://www.mcarmand.co.cc/2008/08/ pencemaran-tanah.html. diakses 20 Desember 2008.

Wardhana, W.A., 1995. Dampak Pencemaran Lingkungan, Andi Offset Yogyakarta, Jakarta. 
Wikipedia. 2008. Pencemaran Tanah (On-line). http://id.wikipedia.org/wiki/pencemaran_ta nah. diakses 20 Desember 2008 